\title{
The Musical Encart of the Royal Printers Le Roy \& Ballard in the 1583 Hours of Jamet Mettayer Held in the Musée de l'Amérique francophone in Quebec City
}

\author{
GENEVIÈVE B. BAZINET \\ University of Ottawa
}

The Heures de Nostre Dame, a l'usage de Rome: selon la Reformation de Nostre S. Pere pape Pie VI pour la Congregation roiale des penitens de l'Annonciation de Nostre Dame, printed at the request of King Henri III by Royal Printer Jamet Mettayer (Paris, 1583) and held at the Musée de l'Amérique francophone in Quebec City, is a rare example of a Book of Hours that contains music. The musical encart printed by the Royal Printers of Music Le Roy \& Ballard (Paris, 1583) follows the texts of the Hours and totals thirty-six pages. This article focuses on the music in the encart and its relationship to the rest of the book, and on references to music in the statutes of the Congrégation. The musical encart is an essential part of this Book of Hours as it provides music for the Hours of the Virgin and the other offices celebrated by the Congrégation, as well as insight into their musical performance practices.

Les Heures de Nostre Dame, a l'usage de Rome: selon la Reformation de Nostre S. Pere pape Pie VI pour la Congregation roiale des penitens de l'Annonciation de Nostre Dame, imprimées à la demande du roi Henri III par l'imprimeur royal Jamet Mettayer (Paris, 1583) et conservées au Musée de l'Amérique francophone dans la ville de Québec, sont un exemple rare d'un livre d'Heures contenant de la musique. L'encart musical imprimé par les Imprimeurs royaux en musique Le Roy et Ballard (Paris, 1583) suit le texte des Heures et compte trente-six pages. Cet article porte sur la musique de l'encart, ainsi que les références à la musique dans les statuts de la Congrégation. L'encart musical est une partie essentielle de ce livre d'Heures puisqu'il comprend la musique des Heures de la Vierge et des autres offices célébrés par la Congrégation, et ouvre une fenêtre sur les esthétiques d'interprétation de la Congrégation.

\footnotetext{
Tn 1583, King Henri III of France extended the reach of his royal authority through the foundation of his royal devotional confraternities. The first of these was the Congrégation des Penitens de l'Annonciation de Notre Dame, which would be renamed the Archicongrégation des Penitens in $1584 .{ }^{1}$ Among

1. The research for this article was funded by the SSHRC grant (2014-18) awarded to the project "Un Catalogue raisonné des livres d'Heures des XVe et XVI e siècles conservés au Québec" directed by Brenda Dunn-Lardeau. Thanks also to the Musée de l'Amérique francophone for its permission to consult the book and its authorization to include images from their book in this article; to Ariane Bergeron for providing valuable information about the copy of the 1583 Book of Hours held at the Bibliothèque
} 
the several documents produced for the Congrégation was the first Book of Hours printed for Henri III's royal confraternities, the Heures de Nostre Dame, a l'usage de Rome: selon la Reformation de Nostre S. Pere pape Pie VI pour la Congregation roiale des penitens de l'Annonciation de Nostre Dame, a copy of which is currently held by the Musée de l'Amérique francophone in Quebec City. ${ }^{2}$ This beautifully preserved book, the only copy held in Quebec collections and one of two copies held in North American collections, holds a special place within the Book of Hours tradition. It bridges the gap between private devotional practices (typical of the Book of Hours tradition) and the public Mass. It also belongs both to the printed Book of Hours tradition and to the printed music book tradition, because of the inclusion of a musical encart, or insert, which follows the Book of Hours proper.

Although the Heures de Nostre Dame 1583 is listed in Lacombe's catalogue of Books of Hours, it has not previously been the subject of a detailed study. This article offers the first in-depth analysis of this important book, with a focus on the musical encart. The article begins with an overview of music printing practices in the sixteenth century. It underlines the challenges of including music in printed books and identifies the printing tradition to which the printers of the musical encart belonged and their important place in French music printing history. The article then situates the book within the Book of Hours and printed music book traditions of the sixteenth century. It also considers the musical encart in relation to the instructions in the Statuts

Sainte-Geneviève; and to Brenda Dunn-Lardeau for her information about the copy held at Nice and her generous comments and suggestions in the editing of this article.

2. Heures de Nostre Dame, a l'usage de Rome: selon la Reformation de Nostre S. Pere pape Pie VI pour la Congregation roiale des penitens de l'Annonciation de Nostre Dame, Quebec City, Musée de l'Amérique francophone (called Musée de l'Amérique française until 2013), 22.7.8 QMUC; hereafter, Heures de Nostre Dame 1583. This copy has been a part of the library of the former Séminaire de Québec, shelf mark SQ042015. There are an additional eight copies of the Heures de Nostre Dame 1583 in libraries worldwide. Paul Lacombe lists three Paris copies in his Livres d'heures imprimés au XVe et au XVIe siècle, conservés dans les bibliothèques publiques de Paris: Catalogue (Nieuwkoop: B. de Graaf, 1963): no. 473 Bibliothèque nationale de France; no. 474 Bibliothèque Sainte-Geneviève; no. 475 Bibliothèque Mazarine. Copies are also held at the Bibliothèque patrimoniale municipale Romain-Gary in Nice, the Bibliothèque municipale in Vesoul, the Bayerische Staatsbibliothek in Munich, the Österreichische Nationalbibliothek in Vienna, and the Morgan Library and Museum in New York. Thanks to Sarah Cameron-Pesant for her assistance in the compilation of this list. 
de la Congrégation des Penitens printed by Jamet Mettayer in $1583 .{ }^{3}$ The book underlines the importance of music in the services of the Congrégation and the role of music in the celebration of the Hours of the Virgin and offices by the confraternity. The musical encart was an essential part of the Congrégation's Book of Hours. It provides a rare record of the musical practices of France's first royal confraternity and is a wonderful example of late sixteenth-century music printing.

\section{Music printing in the fifteenth and sixteenth centuries}

Prior to the late fifteenth century, the reproduction of a text, musical or otherwise, involved a long process of hand-copying performed by individual scribes. By the late fifteenth century, printing had been adopted as a means of dissemination for many types of texts, such as literature, scientific texts, and school primers. ${ }^{4}$ The printer of music, however, still faced several challenges. Apart from the regular difficulties of aligning type and pressing each page of text, the printing of music required a different set of symbols in addition to those used in printing text, a problem complicated by the fact that music in the late fifteenth and early sixteenth centuries could be notated in several different ways: white and black mensural notation, up to three plainchant notations, and lute and keyboard tablatures. ${ }^{5}$ One problem, however, loomed larger than all: how to align the notes on the staff. ${ }^{6}$ As a result, music printing developed at a much slower pace than the printing of texts, and most music circulated primarily in handwritten form well into the sixteenth century. ${ }^{7}$

The first printed books that contained music were liturgical volumes such as missals. For many of these fifteenth-century prints, only the staves and text

3. The statutes of the Congrégation survive in two editions, one printed in 1583 and the other in 1584. The Paris copy of the Heures de Nostre Dame 1583 includes the 1584 statutes. The 1583 statutes are discussed below in relation to the Heures de Nostre Dame and the Congrégation.

4. Stanley Boorman et al., "Printing and publishing of music", in Grove Music Online, Oxford Music Online (Oxford University Press), accessed 30 August 2015, http://www.oxfordmusiconline.com/ subscriber/article/grove/music/40101.

5. Jane A. Bernstein, Print Culture and Music in Sixteenth-Century Venice (Oxford: Oxford University Press, 2001), 20.

6. Bernstein, 20.

7. Boorman, "Printing and publishing of music." 
were printed, with the musical notes added later to the manuscript by hand. ${ }^{8}$ This type of book, along with treatises on music theory, contained a limited amount of music, which made feasible the copying by hand of the music component. But the printers of these types of music incunabula soon solved the problem of printing music by using one of two methods: woodblocks, or a multiple impression process using movable type. ${ }^{9}$

\section{Music printing from woodblocks and the multiple impression method}

Printing from woodblocks naturally produced varied and limited results, as it was both a difficult and time-consuming process. ${ }^{10}$ Printing by the multiple impression method was by far the most common process. In the last quarter of the fifteenth century, some sixty-six printers produced books with music in which both notes and staves were printed by multiple impressions. ${ }^{11}$ The first liturgical book with music printed in this manner was the Gradual for Constance, ca. 1473, in which the staves and text were printed first, followed by the notes and clefs in the second impression. ${ }^{12}$ Both processes continued to be used by printers in the sixteenth century and were adopted by the first printers of polyphonic music in the early 1550s: Ottaviano Petrucci and Andrea Antico. ${ }^{13}$

\section{Printing music from movable type}

The initial process of printing polyphonic music from movable type was essentially the same process developed by Johann Gutenberg for the printing of text some fifty years earlier. The process involved two stages: in the first,

8. Stanley Boorman, Studies in the Printing, Publishing, and Performance of Music in the 16th Century (Burlington, VT: Ashgate, 2005), 226.

9. Bernstein, 20.

10. Boorman, "Printing and publishing of music."

11. Boorman, "Printing and publishing of music." Boorman states that these printers were located in twenty-five cities and used a double-impression method.

12. Alec Hyatt King, “The Significance of John Rastell in Early Music Printing," The Library 26.3 (1971): 198.

13. Polyphonic music involves more than one musical line. Most books of polyphony were printed in partbooks: soprano music in one partbook and tenor in another. 
the type (individual pieces containing a single symbol—a letter or a note) was arranged in the proper order by a typesetter or compositor, and placed into a set or forme. The second stage involved applying ink to the arranged type and passing it through the press, which aligned the type with the paper. ${ }^{14}$ For printing music, however, the process was longer and involved several more stages, since both music and text had to be printed on the same page. There were also notable differences in the amount of material that could be printed. Most printed music books produced in the first half of the sixteenth century contained five to six staves per page, so that even large volumes of music held only a fraction of the material that was printed in non-music books, such as classical texts. ${ }^{15}$

\section{John Rastell and the single impression method}

Petrucci's method of printing at first required three impressions: first the staves, then the notes, and finally the text. He later refined and simplified this method to two impressions, but the process continued to be time-consuming, labour-intensive, and costly. ${ }^{16}$ Despite these limitations, Petrucci's achievement is undeniable: he successfully adapted printing by movable type to produce stunning books of polyphony and ushered in a new era-one in which the amount of music produced was greater than had previously been possible. ${ }^{17}$

In the 1520s a new method of printing music by single-impression was used in London by the English printer John Rastell. ${ }^{18}$ Single-impression printing was the process in which the staves and notes were cast together on a single piece of metal type, and in which the music and text were printed simultaneously. Although Rastell may have been the first printer to use the single-impression method, it was the Frenchman Pierre Attaingnant who refined the process and used it to "propel music printing into a moneymaking enterprise." 19

14. Boorman, "Printing and publishing of music."

15. Boorman, Studies in the Printing, Publishing, and Performance of Music, 225.

16. Bernstein, 21.

17. Boorman, "Printing and publishing of music."

18. King, 213. Rastell may have used the single-impression method as early as 1519.

19. Bernstein, 21. 


\section{Pierre Attaingnant: royal printer of music and refiner of the single impression method}

Though little is known of Attaingnant's early history, records indicate that he was an apprentice to prolific Parisian Book of Hours printer Philippe Pigouchet for several years, during which time he married Pigouchet's daughter Claude. ${ }^{20}$ Attaingnant inherited Pigouchet's printing business and shop in 1514 and spent several years perfecting his new single-impression method of music printing. During these years he also refined his printing and engraving methods on liturgical books, such as the surviving printed Breviary for the use of Noyon, $1525 .{ }^{21}$ He was the first printer in France to employ the single-impression method, which he claimed to have invented, a claim supported by the fact that Attaingnant may very well have designed and engraved the type for his press himself. ${ }^{22}$ In 1531, he applied for and was granted a royal privilege to protect past, present, and future music prints.

Attaingnant was arguably the first and most important printer of polyphonic music in France in the sixteenth century; he produced 165 prints containing masses, chansons, instrumental music, and motets ${ }^{23}$ including his monumental motet series, a series of thirteen books printed between 1534 and 1535 which were all anthologies, and the fourteenth book printed in 1539 which was Attaingnant's first single-composer motet print. He was also the first to be granted the coveted title of royal printer of music. ${ }^{24}$

The impact of the single-impression method on the music printing industry cannot be overstated. Indeed, with the single-impression method that Attaingnant used, music books soon became much more affordable than manuscripts or multiple impression prints, making them accessible to many

20. Daniel Heartz, Pierre Attaingnant: Royal Printer of Music: A Historical Study and Bibliographical Catalogue (Berkeley and Los Angeles: University of California Press, 1969), 36-37.

21. Heartz, 57-58. Heartz describes the Breviary (for the use of Noyon) as a single volume, measuring $9 \times 14.5 \mathrm{~cm}$, in sextodecimo format (211).

22. Heartz, 56-60. Attaingnant's claim is as inventor of this type of printing in France. The claim is printed in the privilege that Attaingnant received from the king in 1531.

23. Heartz, 210-377. Heartz lists 165 individual music titles in his catalogue.

24. On Attaingnant, see the definitive study by Heartz. 
more people than before. ${ }^{25}$ It was subsequently adopted by music printers in other French cities, by various printers in Italy, and by the next French royal printers of music, Le Roy \& Ballard (see Fig. 1).

\section{Le Roy \& Ballard: royal printers of music, followers of the single impression method}

Adrian le Roy was born in 1520 to a prominent merchant family in northern France, and became a virtuoso lutenist and a composer. ${ }^{26}$ In 1546, he made the acquaintance of the editor Jean de Brouilly and subsequently married de Brouilly's daughter. ${ }^{27}$ After moving into his father-in-law's house in the rue St-Jean de Beauvais, he established a printing house with his cousin Robert Ballard, who later married the daughter of the king's organist. ${ }^{28}$

Le Roy and Ballard's intimacy with members of the French court and Le Roy's court connections provided the two printers with access to the most popular musicians of the time and undoubtedly contributed to their success as music printers. ${ }^{29}$ The two cousins each took responsibility for different elements

25. Bernstein, 79. Bernstein gives the price of four partbooks of five gatherings as 1 lira and 4 soldi in Italy in 1543. Boorman equates this to 26 soldi, and notes that it was significantly less than the price of a Petrucci print in 1530; see Stanley Boorman, Ottaviano Petrucci: Catalogue Raisonné (Oxford: Oxford University Press, 2006), 336. In 1544, an Attaingnant print of Sermisy motets (S 2818) was valued at the lower price of twelve sous, the French sous being more or less equal to the Italian soldi (Heartz, 126). The Attaingnant print had only four gatherings, not five; the price is therefore not dramatically lower than the Italian partbooks.

26. Samuel F. Pogue and Frank Dobbins, "Le Roy, Adrian," in Grove Music Online, Oxford Music Online (Oxford University Press), accessed 13 November 2015, http://www.oxfordmusiconline.com.proxy.bib. uottawa.ca/subscriber/article/grove/music/16467.

27. Pogue and Dobbins, "Le Roy, Adrian."

28. François Lesure and Geneviève Thibault, Bibliographie des éditions d'Adrian Le Roy et Robert Ballard, 1551-1598 (Paris: Heugel, 1955), 10-11. The general consensus among music scholars is that Le Roy and Ballard were cousins; however, George Lepreux had earlier identified them as half-brothers and brothersin-law, in Gallia typographica, ou Répertoire biographique et chronologique de tous les imprimeurs de France depuis les origines de l'imprimerie jusqu'à la révolution (Paris: H. Champion, 1908-14), 65, 374. Philippe Renouard also identifies them as half-brothers in his Répertoire des imprimeurs parisiens: libraires, fondeurs de caractères et correcteurs d'imprimerie: depuis l'introduction de l'imprimerie à Paris (1470) jusqu’à la fin du seizième siècle (Paris: M. J. Minard, 1965), 16, 273.

29. Lesure and Thibault, 14-15. 
of the business. Le Roy was in charge of the artistic aspects of the enterprisethe editing of the music and the selection of pieces-while Ballard looked after the business side..$^{30}$ On 14 August 1551, Le Roy \& Ballard was accorded a nineyear royal privilege from King Henri II for the printing and selling of music (vocal or instrumental), and produced its first print by the end of August of that same year. ${ }^{31}$

Less than two years later, on 16 February 1553, Le Roy and Ballard were named royal printers of music by Henri II, the same position previously held by Attaingnant. ${ }^{32}$ Their title was subsequently renewed twice, first in 1568 by Charles IX and again in 1594 by Henri IV..$^{33}$ Le Roy \& Ballard produced more than three hundred prints, including music for the Mass, motets, collections of psalms and canticles, French, Italian, and Spanish songs, and music treatises. They were also occasionally called upon to print special works for the king or other nobles. ${ }^{34}$ One of these works was surely the musical encart printed for a Book of Hours designed for the Parisian Congrégation Royale des Penitens.

\section{The Congrégation des Penitens and their devotional practices and activities}

The Congrégation des Penitens de l'Annonciation de Nostre Dame, established in 1583, was the first of many confraternities founded by King Henri III of France. The principal objectives of the confraternity were to promote devotions and provide an opportunity for men of different rank to congregate and interact anonymously. ${ }^{35}$ To this effect, the members of the confraternity were required to wear the habit of the Congrégation (the same habit for all members), which included full head covers (see Fig. 1 below). According to the Statuts de la Congrégation des Penitens printed in 1583 by Jamet Mettayer, members were to wear their habit each time they entered the chapel for services, and for the three yearly processions. ${ }^{36}$ The initial membership of the Congrégation was

30. Lesure and Thibault, 13.

31. Lesure and Thibault, 12.

32. Attaingnant died in 1552. The post was vacant until 1553 .

33. Lesure and Thibault, 12.

34. Lesure and Thibault, 13.

35. Jacqueline Boucher, La cour de Henri III (Rennes: Ouest-France, 1986), 194.

36. Statuts de la Congrégation des Penitens (Paris: Jamet Mettayer, 1583), 26. See rule 30. 
three hundred confrères, and included the king and his inner circle, as well as members from both the laity (a high percentage of noblemen from the noblesse d'épée, and some high- and mid-ranking Parisians) and the clergy (mostly clergy already established at the royal court). ${ }^{37}$ As Pierre de l'Estoile, royal secretary to the king, states in his journal:

[...] le Roy institua et érigea une nouvelle Confrairie qu'il fist nommer des Penitents, de laquelle lui et ses deux mignons se firent confrères, et y fist entrer plusieurs seingneurs, gentilshommes et autres de sa Cour, y conviant les plus apparans de son Parlement de Paris, Chambre des Comptes, et autres Cours et jurisdictions, avec un bon nombre des plus notables bourgeois de la Ville [... $]^{38}$

Each Confrère was also held to a series of statutes concerning their daily devotional activities, acts of charity, and weekly congregational devotions. In particular, they were to attend the Office of the Hours of the Virgin, following the standard form of the Book of Hours, which was held every Wednesday, as well as services on special feast days. The texts and directions for these services and others for Holy week were printed for the Congrégation by Jamet Mettayer in the Heures de Nostre Dame, a l'usage de Rome: selon la Reformation de Nostre S. Pere pape Pie VI pour la Congregation roiale des penitens de l'Annonciation de Nostre Dame.

\section{The Book of Hours and music: an overview}

The Book of Hours was a personal and private devotional prayer book, intended for use by the laity, that first appeared in the thirteenth century. It was an

37. Boucher, La cour de Henri III, 195. Boucher states that 75 percent of the members of the Congrégation in 1583 were from the court.

38. Gustave Brunet et al., eds., "Journal de Henri III, 1581-1586," in Mémoires-journaux de Pierre de l'Estoile, 12 vols. (Paris: Librairie des Bibliophiles, 1875-96), 2:109. L'Estoile's complete Registres-Journal from the time of Henri III was recently edited by Madeleine Lazard and Gilbert Schrenck, in Pierre de l'Estoile, Registre-Journal du règne de Henri III, 6 vols. (Geneva: Droz, 1992-2003). The pious first procession of the congregation, which ended in heavy rain, prompted a satirical quatrain in which the author mocked the "soaked sac" worn by the king. The quatrain is included in the Journal after L'Estoile's account of the procession (2:111). 
adapted form of the Breviary and the Office of the Blessed Virgin, and quickly became the most popular type of book-both in manuscript form and, by the end of the fifteenth century, in printed form as well. ${ }^{39}$ With over 1,585 editions printed from the late fifteenth century and through the sixteenth century, it is no wonder that the Book of Hours is generally referred to as the "bestseller" of the Middle Ages and Renaissance. ${ }^{40}$ The popularity of the Book of Hours was threefold: it provided the laity with a simple and easy devotional "tool" with which to imitate the practices of monastic life; it offered them "an intimate conversation with one of the most important people in his or her life: the Virgin Mary"; ${ }^{41}$ and it could feature sumptuous illustrations and was therefore a work of art, something to display and treasure.

A Book of Hours contained many texts commonly found in the liturgy as chants, but did not typically include music. ${ }^{42}$ Many of these Books of Hours' texts were, however, set to music by composers in the late fifteenth and early

39. Roger S. Wieck, Time Sanctified: The Book of Hours in Medieval Art and Life (New York: George Braziller with The Walters Art Gallery, 1988), 27.

40. Henri-Jean Martin, Roger Chartier, and Jean-Pierre Vivet, eds., Histoire de l'édition française, 3 vols. (1982; Paris: Promodis, 1986), 1:212. The precise number of editions produced during this time remains uncertain. No two scholars agree on the total number of prints that were produced.

41. Wieck, 27.

42. Lacombe lists four other printed Books of Hours from the sixteenth century with music in them: Heures des trois Maries printed in 1529 (no. 384 and its copies, nos. 385-389), Heures à l'usage de Paris dated 1582 by Lacombe (no. 472); Heures à l'usage de l'Oratoire Notre-Dame de Vie-Saine printed by Mettayer in 1584 (no. 479), and the Heures à l'usage de l'Oratoire Notre-Dame de Vie-Saine printed by Mettayer in 1586 (no. 484), both for Henry III's Vie-Saine confraternity. There is also a Parisian manuscript Book of Hours for Benedictine use, ca. 1519 at the Newberry Library that contains chant incipits (Chicago: Newberry Library MS 5065). Mettayer's Heures de Nostre Dame of 1583 was the first Book of Hours with music produced specifically for a royal confraternity in Paris. While MS 5065 and the Mettayer 1584 have only a few lines of music, Lacombe's descriptions of the 1529 (no. 384), the 1582 (no. 472), and the 1586 (no. 484) indicate that these books had more extensive music notation. The author is currently undertaking a study of these books in relation to Mettayer's Heures de Nostre Dame of 1583 and has found that the 1582 (no. 472) contains notated music on more than half of its pages. Findings from the study indicate that the format and music of the 1582 are markedly different from the format and music of Mettayer's Heures de Nostre Dame of 1583. I have also found that the 1586 (no. 484) contains 129 pages with integrated music notation. This ongoing study will determine to what degree, if any, the 1586 draws on the formatting and music of the 1583 edition. Preliminary findings of this study were presented at the Annual Meeting of the Canadian University Music Society, Calgary, 1-3 June 2016. 
sixteenth centuries as motets - a genre of music positioned between the musical Mass and the secular chanson, which served many different functions both within and outside the liturgy. ${ }^{43}$ In fact, Attaingnant included more than one hundred motets based on texts found in Books of Hours in his fourteen book motet series printed between 1534 and 1539. ${ }^{44}$ Owners of Books of Hours who wished to sing the texts in their Books of Hours would have looked to books such as Attaingnant's series or liturgical music books to find the music they needed. The Book of Hours printed by Mettayer for the Congrégation des Penitens is one of the rare examples of a Book of Hours printed with music as an integral part of the book.

\section{The case of the Heures de Nostre Dame 1583: a Book of Hours with a music section}

The Heures de Nostre Dame, a l'usage de Rome: selon la Reformation de Nostre S. Pere pape Pie VI pour la Congregation roiale des penitens de l'Annonciation de Nostre Dame was printed in 1583 by Jamet Mettayer and Le Roy \& Ballard. Mettayer was named royal printer and bookseller for mathematics in 1573 or 1580 , and in subsequent years-either 1580 or 1583-became "Imprimeur ordinaire du roi." ${ }^{35}$ Heures de Nostre Dame was the first book he printed for the royal congregations, and he was eventually named the official printer for all royal congregations in Paris. ${ }^{46}$ In addition to the standard Book of Hours texts,

43. On the uses for the motet, see Julie E. Cumming, The Motet in the Age of Dufay (New York: Cambridge University Press, 1999); Jeremy Noble, “The Function of Josquin's Motets," Tijdschrift van de Vereniging voor Nederlandse Muziekgeschiedenis 35.1-2 (1985): 9-22; Howard Mayer Brown, “The Mirror of Man's Salvation: Music in Devotional Life about 1500," Renaissance Quarterly 43.4 (1990): 744-73; Anthony M. Cummings, “Towards an Interpretation of the Sixteenth Century Motet," Journal of the American Musicological Society 34.1 (1981): 43-59; Geneviève Bazinet, Pierre Attaingnant's Encyclopedia of Sacred Music: The 1534-1539 Motet Series (PhD dissertation, McGill University, 2013).

44. Bazinet, 259-63.

45. Laurence Augereau, “Tours, capitale provisoire du royaume, 1589," in Henri III mécène: des arts, des sciences et des lettres, ed. Isabelle de Conihout, Jean-François Maillard, and Guy Poirier (Paris: Presses de l’Université Paris-Sorbonne, 2006), 219.

46. Bruno Petey-Girard, "Le mécénat de la parole: l'esthétique spirituelle dans les oratoires royaux," in Conihout, Maillard, and Poirier, eds., 171. 
it includes many elements that were uncommon in traditional Books of Hours. ${ }^{47}$ Mettayer's Book of Hours contains an entire section of music, a feature that gives special importance to this book. This inclusion of music, as well as the explicit instructions for the singing of the psalms, antiphons, and hymns, points to a different usage than that for a traditional Book of Hours, and was clearly designed for the collective rather than individual devotions of the Congrégation. ${ }^{48}$

The musical encart printed by Le Roy \& Ballard at the end of the book consists of thirty-six pages of music for use with several texts of the Hours of the Virgin and various other offices included in the Mettayer part of the book. ${ }^{49}$ While the title on the first page of the musical encart states that what follows are psalms and canticles, the encart actually includes music for twenty-seven different texts found in the text section, including psalms and canticles, as well as antiphons, hymns, lamentations, and lessons.

The encart contains gilt-edged leaves in five in-quarto folio gatherings signed A-E, with two blank leaves at the end of gathering E. ${ }^{50}$ The page size is approximately $255 \mathrm{~mm} \times 180 \mathrm{~mm}$, with both red and black staff lines. ${ }^{51}$ Red ink is used throughout the encart and the text section for certain capital letters, as well as running heads, titles, and rubrics. French text in the text sections and in the encart appears almost exclusively in red ink, while the Latin texts are

47. The book was designed for communal rather than private devotions, a trait I will discuss in relation to its other unusual feature-the musical encart.

48. Boucher, La cour de Henri III, 1033. Boucher uses the phrase "collectif et non personnel" to describe the use of the psalters and copies of the Offices of the Virgin requested by Henri III, a term that seems apt for the devotions of the Congrégation, whose services were exclusively for the Confrères. Please refer to the introduction by B. Dunn-Lardeau in this issue for a discussion of the elements of post-Tridentine piety included in Books of Hours, in particular the bona opera.

49. The encart is listed in Lesure and Thibault's catalogue of prints by Le Roy \& Ballard (no. 257).

50. The pages of the text section of the book printed by Mettayer are likewise gilt-edged and of the same size.

51. Red staff lines appear on pages $15,17,19,23,25,27,29,31$, and 33 and were used to fill in blank spaces below the music when no directions (rubrics in red) were printed. They do not contain music, but rather seem to have been included to avoid having empty space on the page. The space would not have been filled in with the next piece (started on the next page), since this would have resulted in an impractical and visually clumsy format wherein the singer would be required to turn the page in the middle of a piece. In the actual presentation, each piece is printed on a single page or opening, resulting in a practical and aesthetically pleasing format. 
Les $P$ falmes \& Cantiques qu'on chante en la Chapelle de $\mathrm{l}_{2}$ Congregation à cerrains jours.

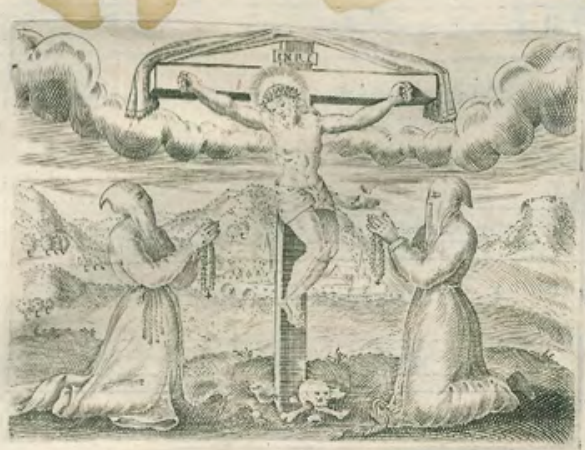

Antienne. à Matines, \& a toutesles heures.
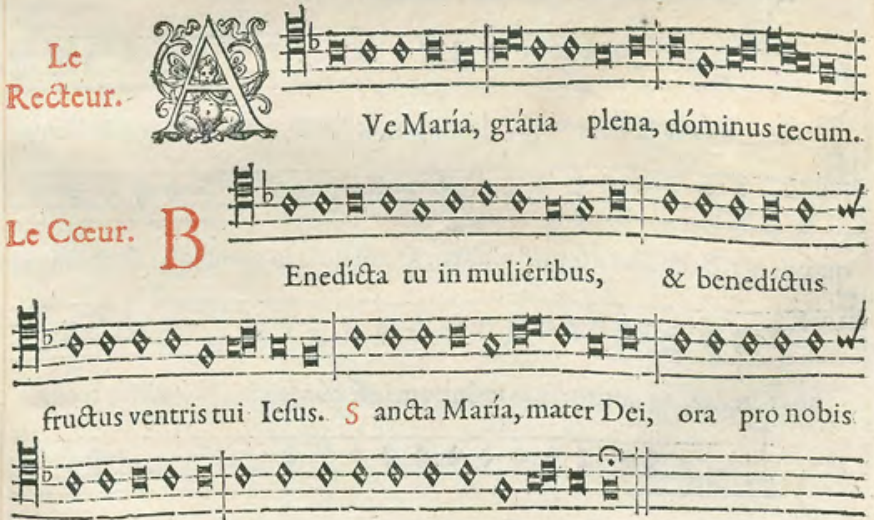

peccatóribus nunc \& in hora mortisnoftrx, Amen.

Fig. 1. First page of the musical encart by Le Roy \& Ballard with the section title, an engraving, and the antiphon "Ave Maria" which opens the Hours of the Virgin. Quebec City, Musée de l'Amérique francophone, 22.7.8 QMUC. 
typically in black ink. ${ }^{52}$ The music of the encart was printed using the singleimpression printing method, as can be seen in the slight brakes in the staff lines created by separate pieces of type (see Fig. 1 and Fig. 3 for examples). ${ }^{53}$ The final page of the music fascicle includes the printers' mark and colophon, which identify Le Roy \& Ballard as royal printers, confirming the fact that there were indeed two printing houses involved in the printing of this book. There is also an initial above the colophon, after the word "Finis"-an " $H$ " surrounded by laurels, possibly a reference to Henri III. ${ }^{54}$

Table 1: Contents of the musical encart by Le Roy \& Ballard with title, first line, and page number.

\begin{tabular}{|l|l|l|}
\hline $\begin{array}{l}\text { Title of the music item or } \\
\text { section }\end{array}$ & $\begin{array}{l}\text { First line of the music text and } \\
\text { colophon }\end{array}$ & Page \\
\hline $\begin{array}{l}\text { Antienne, à Matines, \& à toutes } \\
\text { les heures }\end{array}$ & Ave Maria, gratia plena & 1 \\
\hline Invitatoire à Matines & Ave Maria, gratia plena & 2 \\
\hline Psalme & Venite exultemus domino & 2 \\
\hline Hymne à matines & Quem terra & 4 \\
\hline Psalme à matines & Domine dominus noster & 4 \\
\hline $\begin{array}{l}\text { Leçcon du premier office de } \\
\text { nostre Dame }\end{array}$ & Iube Domine benedicere & 5 \\
\hline Pemiere leçcon & In omnibus requiem quaesivi & 5 \\
\hline
\end{tabular}

52. Exceptionally, some French texts printed in sections after the hours and offices, notably in the Breve instruction, are printed in black ink. Red ink is also used for the Hebrew letters in Latin transliteration at the start of each verse of the Lamentations of Jeremiah (pages 16-31 of the encart), which is in keeping with traditional liturgical practices.

53. The single impression method was used for text and music printed in black ink. The texts that appear in red in the encart were printed on separate runs, as can be seen in the uneven placement of the two red capital letters in Fig. 3 (the " $\mathrm{A}$ " of Ave Maria halfway down the page, and the "D" of Dominus tecum on the second-last staff line).

54. The initial also appears in the 1610 music book Second livre d'airs a quatre de differens auteurs printed by Pierre Ballard (Bibliothèque nationale de France, département Musique, RES-27), though in this case it would have been a reference to Henri IV. 


\begin{tabular}{|c|c|c|}
\hline Seconde leçcon & Iube Domine benedicere. & 6 \\
\hline Troisiesme leçcon & Iube Domine benedicere. & 7 \\
\hline $\begin{array}{l}\text { Premiere leçcon du second office } \\
\text { de nostre Dame }\end{array}$ & Iube Domine benedicere. & 8 \\
\hline Seconde leçcon & Iube Domine benedicere. & 9 \\
\hline Troisiesme leçcon & Iube domine benedicere. & $9-10$ \\
\hline $\begin{array}{l}\text { Cantique de sainct Ambroise et } \\
\text { sainct Augustin }\end{array}$ & Te Deum laudamus & 11 \\
\hline Cantique des trois Enfans & $\begin{array}{l}\text { Benedicite omnia opera domini } \\
\text { domino }\end{array}$ & 14 \\
\hline Hymne à laudes & O gloriosa domina & 14 \\
\hline Cantique de Zacharie & Benedictus Dominus Deus Israël & 14 \\
\hline Hymne & Ave maris stella & 15 \\
\hline $\begin{array}{l}\text { Hymne à Complies, et autres } \\
\text { heures }\end{array}$ & Memento salutis auctor & 15 \\
\hline $\begin{array}{l}\text { Premiere Lamentation du } \\
\text { premier Nocturne des tenebres } \\
\text { du Mercredy }\end{array}$ & $\begin{array}{l}\text { Incipit lamentatio Hieremiae } \\
\text { Prophetae. Aleph. }\end{array}$ & 16 \\
\hline Seconde Lamentation & $\begin{array}{l}\text { Vau. Et egressus est a filia Sion } \\
\text { omnis decor eius }\end{array}$ & 18 \\
\hline Troisiesme Lamentation & $\begin{array}{l}\text { Iod. Manum suam misit hostis ad } \\
\text { omnia desiderabilia eius }\end{array}$ & 20 \\
\hline $\begin{array}{l}\text { Premiere Lamentation du } \\
\text { premier Nocturne des Tenebres } \\
\text { du Jeudy }\end{array}$ & $\begin{array}{l}\text { De lamentatione Hieremiae } \\
\text { prophetae. Heth. }\end{array}$ & 22 \\
\hline Seconde Lamentation & Lamed. Matribus suis dixerunt & 24 \\
\hline Troisiesme Lamentation & $\begin{array}{l}\text { Aleph. Ego vir videns } \\
\text { paupertatem meam }\end{array}$ & 26 \\
\hline $\begin{array}{l}\text { Premiere lamentation du premier } \\
\text { Nocturne des tenebres du } \\
\text { Vendredy }\end{array}$ & $\begin{array}{l}\text { De lamentatione Hieremiae } \\
\text { Prophetae. Heth. }\end{array}$ & 28 \\
\hline
\end{tabular}




\begin{tabular}{|l|l|l|}
\hline Seconde Lamentation & $\begin{array}{l}\text { Aleph. Quomodo obscuratum est } \\
\text { aurum }\end{array}$ & 30 \\
\hline Troisiesme Lamentation & $\begin{array}{l}\text { Incipit oratio Hieremiae } \\
\text { Prophetae. Recordare Domine } \\
\text { quid acciderit nobis }\end{array}$ & 32 \\
\hline $\begin{array}{l}\text { Prose qui se dit es messes des } \\
\text { Trespassez }\end{array}$ & Dies irea & 34 \\
\hline Colophon & $\begin{array}{l}\text { A Paris. De l'imprimerie d'Adrian } \\
\text { le Roy, \& Robert Ballard, } \\
\text { Imprimeurs du Roy, en Musique. } \\
\text { M.D.LXXXIII }\end{array}$ \\
\hline
\end{tabular}

The music included in this section represents a variety of genres of texts, including the lessons and psalms that were chanted, and antiphons and hymns that were generally sung to a more elaborate melody. ${ }^{55}$ The majority of the musical pieces in the encart are set in simple recitation style, resembling psalm or lesson tones. For example, the opening "Ave Maria" is labelled as an antiphon in the encart, but does not conform to standard Roman liturgical melodies for the antiphon; rather, it is set in simple recitation style, using the same melody printed for the invitatory setting of the text on page 2 of the musical encart. The apparent simplification of the liturgical melody may have been to accommodate the singers of the Congrégation. ${ }^{56}$

55. Antiphons in particular could be more elaborate than a simple recitation-style psalm tone.

56. Preliminary research into the sources of the melodies of the encart connects some of the music to contemporary liturgical chants for the use of Rome. For example, the melody "Ave maris stella" on page 14 corresponds to the traditional use of Rome liturgical melody for that hymn. However, the "Lamentations" and other hymns do not conform to the use of Rome. Since the hymns all use the same melody, with the exception of "Ave maris stella," it may be that this melody was adapted for the Congrégation from another chant. Cursory searches in Cantus Database: Inventories of Chant Sources (http://cantus.uwaterloo.ca) and Cantus Index: Catalogue of Chant Texts and Melodies (http:// cantusindex.org/) yielded no matches for this melody. Further research is underway and will hopefully lead to the identification of the sources of the melodies printed in this encart. 


\section{The extent of the collaboration between the printing houses of Mettayer and Le Roy \& Ballard}

The book consists of two sections: texts and music. The text section of the book includes the title page and Mettayer's colophon, the calendar, the table of contents (which mentions the encart), and the directives and instructions for members of the Congrégation, as well as the Hours of the Virgin, the Offices of the Dead, and the Offices for Holy Week and the Passion. The musical encart, the second part of the book, mirrors the overall appearance of the text section, particularly in the section of the Hours of the Virgin. More specifically, the fonts in the two parts of the book are similar, and both make use of the contrast of black and red ink-which was typically used in musical and non-musical liturgical and devotional books. Also of note is the use of decorated initials in the encart in similar style to the initials found in the first part, and the inclusion by Le Roy \& Ballard of an engraving on the first page of their fascicle which appears beforehand in the Mettayer part of the book. In fact, the engraving on page 1 of the encart is the same as the engraving that appears on the first page of the Office for Holy Friday in the Mettayer text section of the book ${ }^{57}-\mathrm{a}$ reflection of the overall trend of the book..$^{58}$ (See Fig. 1 for the engraving on page 1 of the musical encart). The production of this book therefore shows some clear signs of collaborative effort; while each printing house would have been responsible for its own sections, an effort was evidently made to ensure that the entirety of the book had a uniform style and layout.

\section{How to use the musical encart of Le Roy \& Ballard}

The music printed by Le Roy \& Ballard in the encart is clearly designed to provide music for those using the text portion of the Book of Hours. It provides suitable melodies for the singing of some of the most frequently sung texts in the book, including the "Ave Maria," and also the hymn "Memento salutaris," which appears a total of sixteen times throughout the various hours and offices. It also features music for the lamentations, texts that appear only in the Offices for Holy Wednesday, Holy Thursday, and Holy Friday. The question of how the

58. The Office of the Hours, Office of the Passion, and Office of the Dead each open with an engraving. 
Congrégation used the two sections together may be answered through careful examination of the encart in tandem with the text section of the book and the Statuts de la Congrégation des Penitens, printed separately by Mettayer in 1583.

Le Roy \& Ballard provides some essential information regarding the performance practices of the Congrégation along with the music. This information comes in two types of directions. The first set of directions relates to the music printed on the page. For example, we can see that the opening "Ave Maria" is designed for performance in responsorial style. At the head of each section, the printers include a rubric that indicates which group or individual should sing the music. For example, "Le Recteur" appears next to the first line "Ave Maria gratia plena dominus tecum," while "Le chœur" is printed in front of "Benedicta tu in mulieribus." The corresponding section in the text section of the book also indicates this style of performance; the first page of music is therefore clearly designed to accompany the first folio of the Hours (compare Fig. 1 and 5). ${ }^{59}$

The second type of directions provided by the printers relates to music that was to be sung during the hours, but that is not explicitly included in the encart. On page 4 of the encart we are given the words and the music for the first verse of the hymn "Quem terra," a hymn that first appears in the Hours of the Virgin on folio $2 \mathrm{r}$ of the text section (Fig. 2).

The printers added a note informing the singers that the music should also be used for the singing of all other hymns in the Hours of the Virgin, with the exception of the hymn "Ave maris stella," which is set to a different melody and is included on page 15 of the musical encart. ${ }^{60}$ Similar instructions are provided with the music for the Psalm 8 "Domine dominus noster" on page 4 , which Le Roy \& Ballard state is the same melody that should be used to sing all other psalms of the hours and the office. This, however, excludes Psalm 94, "Venite exultamus," for which the music printers provide a separate melody on page 2.

59. A similar set of directions is included for the "Cantique de sainct Ambroise et sainct Augustin" on page 11 of the musical encart, where we see that the phrases of the music are divided between "le chœur" and "les Choristes."

60. There are, in fact, several other hymns whose melody is included in the encart: the Lauds hymn "O gloriosa domina" on page 14 and the Compline hymn "Memento salutis" on page 15. Both hymns use the same melody as "Quem terra." 
depuisla Purific.iufques à l'Aduent. 2 omnes Deos,quóniam nó repéllet Dóminus plebem fuam: quia in manu eius funt omnes fines terræ, \& $\Sigma$ altitúdines móntiú ipfe cónfpicit. Le chœur. Dñs tecú. Les Choriftes. $Q$ uóniam ipfíus eft mare, \&ipfe fecit illud, \& áridam fundauérunt manus eius,veníte, adorémus $\&$ procidámus ante Deum : plorémus coram Dómino qui fecit nos, quia ipfe eft Dóminus Deus nofter, nos autem pópulus eius, \& oues páfcuæ eius. Le chœur. Aue María,gratia plena, Dóminus tecum. Les Choriftes.

Hódie fi vocem cius audiéritis, nolíte obduráre corda veftra: ficut in exacerbatióne fecúndum diem tentatiónisin deférto,vbi tentauérunt me patres veftri, probauérunt \& vidérút ópera mea. Lechour. Dóminus tecú. Les Choriftes. Qưadragínta annis próximus fuigeneratióni huic, \& dixi, femper hi errant corde:ipfi verò non cognouérút vias meas, quibusiuraui in ira mea, fi intró́bunt in réquiem meam. Lo chour. Aue María, grátia plena, Dóminustecum.Les Choriftes. Glória patri.Le chour. Dóminus tecum.Les Choriftes. Aue María, grátia plena. Le chøeur. Dóminus tecum. L'vn des Choriftes commencera l'Hymne, lequel fe chante parlechourà vn verfer pour chaque colté, eftant tous les Penitensàgenoux.
Vem terra, pontus, ǽthera,
Le premier chourfuyue,
Colunt, adórant,prǽdicant,
Trinam regéntem máchinam
Clauftrum Maríx báiulat.
Le fecond chour.
Cuiluna,Sol,\&ómnia
Deféruiunt per témpora,

Hymne.

a ij

Fig. 2. The Mettayer Hours of the Virgin, with the hymn "Quem terra." Quebec City, Musée de l'Amérique francophone, 22.7.8 QMUC, folio 2r. 


\section{Singing from both sections of the Heures de Nostre Dame 1583: the instructions for Psalm 94}

With all these directions, it might appear that the printers had provided ample directions for the singing of the music during the hours and offices, but a cursory glance at the text section where these musical items occur reveals that we only truly get the "whole picture" of the musical performance practice of the Congrégation when we use the text and music sections together.

Psalm 94 clearly illustrates the interdependency of the two sections of the book and the multiple performance practices that could occur for a single text. The music for the psalm is found on pages 2 to 5 of the musical encart, and the text of the psalm is included at Matins of both the Hours of the Virgin and the Office of the Dead. ${ }^{61}$ The psalm is sung with interjections of the "Ave Maria."

The music printed by Le Roy \& Ballard on pages 2 and 3 provides the melody for each verse of the psalm, with the parts of the "Ave Maria" invitatory interjected at the end of each verse. ${ }^{62}$ In Figure 3, we see that the first verse is sung over three staff lines, and the "Ave Maria" is added at the end, with the red letter "A" indicating a new section. Red is also used to signal the start of all subsequent verses of the psalm and phrases from the "Ave Maria." In music notation of the sixteenth century, the vertical lines that one finds in the staff lines indicate the end of a phrase or a pause during which the singer takes a breath. In the music printed by Le Roy \& Ballard, the vertical lines sometimes coincide with a change of performing group, and by extension indicate a responsorial style of performance for the music. But it does not indicate which singers were involved in the performance of the psalm, or what sections they should sing. The performance groups are only indicated in the corresponding text sections of the hours and offices. We find the first appearance of the text of this psalm on folio 1v of the Premier Office des Matines depuis la Purification jusques à l'Advent at the start of the Hours of the Virgin. 
2

\section{Inuitatoire à Matines.}

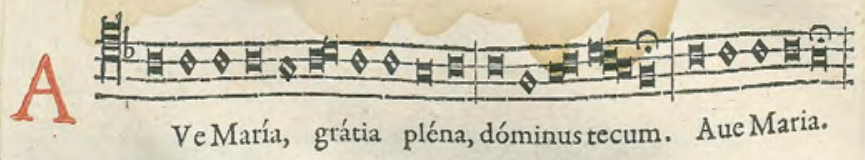

\section{Pfalme.}

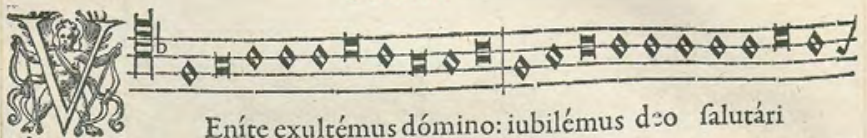
fld noftro: præoccupémusfaciem cius in confeffióne: \& in pfalmis 宸<smiles>C#CCCCC</smiles>

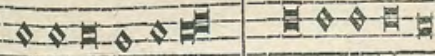

iubilémus ei,

A ue Maria.

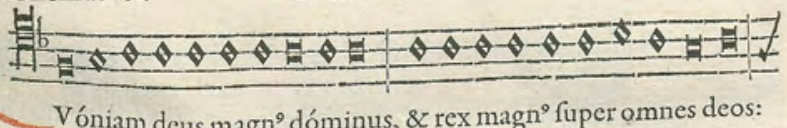

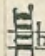

Vóniam deus magn ${ }^{2}$ dóminus, \& rex magn ${ }^{9}$ fuper omnes deos:

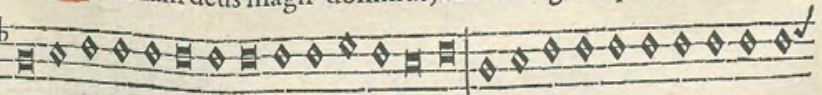
quóniam nô repéllet dómin plebem fuam: quia in manu cius funt omnes 斯古
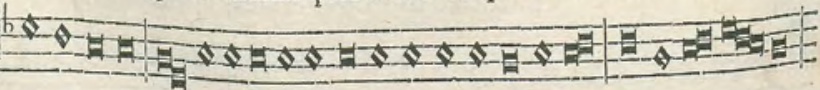

fines terræ, \& altitúdines móntium ipfe cónfpicit. Dóminus tecum. 를 点

Vóniam ipfíus eft mare, \& ipfe fecit illud: \&cáridam funda-

Fig. 3. The Le Roy \& Ballard musical encart with the music for the invitatory "Ave Maria" and Psalm 94 "Venite, exultemus domino." Quebec City, Musée de l’Amérique francophone, 22.7.8 QMUC, page 2. 


\section{Le premier Office de Matines,}

iufques fur la poitrine, le Recteur entonnera, Deus in adiutórium meum inténde. Tous refp. Dómine ad adiuuándum me feftína.

Glória Patri, \& F F́lio: \& Spirítui fancto.

Tous inclineronc la tefte, comme ilsferontà tous les Gloria. Sicut erat in princípio, \& nunc \& femper: \& in fácula fxculórum, Amen. Haléluiah.

Faut noter quelon ditHaléluiah, depuis Pafque iufques au dimanche dela Septuagefime àtoutes les Heures : mais depuis le dimanche de la Septuagefime iufques à Pafques on dic, Laus tibi Dómine rex ætérnæ glóriæ.

Apres, tous les Penitens eftant debout, les deux Choriftes deuant le grand Autel, commenceront à haute voix l'Inuitatoire (Etfaut que chacun prenne garde de chanter pofément les Pfalmes, les bien punctuer, \& farre vne pofe là où. ils verront qu'ily aura deux poincts, ainfi( $(\Leftrightarrow)$ Et quand ce poinct fe trouuera deuanc les deux points, ou apres, comme aduient quelques fois, ainfi $(g)$ il faudra auffi faire vn peu de pofe) Aue María, grátia plena, Dóminus tecum. Le choeur refpord le mefme, Aue María, grátia plena, Dóminus te cum. Ies deux Choriftes fuiurót. (Depuis le Samedy Saint, iufques au Samedy deuant la Trinité,á Vefpres lon adioußte à la fin de l'Inuitatoire Haléluiah. Et auffi à la fin de toutes les Antiennes, \& 2 de tous les Verfets)

Plalme94. (c) Eníte, exultémus Dómino,iubilémus Deofalutá 2. 18 ri noftro: præoccupémus faciem eius in confeffió12 ne, \& in pfalmisiubilémus ei. Le choeur Aue MaChariftes fuiuront, ría, grátia plena, Dóminus tecum. Les deux.

Quóniam Deus magnus Dóminus, \& rex magnus fupes.

Fig. 4. The Mettayer Hours of the Virgin, with the directions for singing the psalm "Venite, exultemus domino." Quebec City, Musée de l’Amérique francophone, 22.7.8 QMUC, folio 1v. 
The instructions for the performance of the psalm in the Mettayer text section are printed in red. These instructions indicate that after the invitatory (which is found in the Le Roy \& Ballard music section on page 2, directly above the music for Psalm 94), the two Choristes begin the psalm and sing the opening verse. They are followed by the chour, who sings "Ave Maria, gratia plena, dominus tecum," printed in black. The Choristes then sing the second verse and are followed by the chœur, who sings "Dominus tecum." This alternatim style (Choristes then chour, and so on) directly corresponds to the layout of the music on pages 2 to 3 , including the placement of the invitatory just before the psalm. But it is only when we use the directions on folio $1 \mathrm{v}$ of the Mettayer text section, in conjunction with the music on pages 2 to 3 of the musical encart, that we arrive at the method of singing the music used by the confraternity in $1583 .{ }^{63}$ The performance of this psalm during the Office of the Dead is somewhat different, but still requires both the music and text sections in order to properly sing the psalm. ${ }^{64}$

\section{The singers of the Congrégation: the Choristes, the musiciens, and the choeurs}

Having established how the confraternity used the book to perform the music for its services, the question now becomes who, precisely, sang the music? A comparison of the musical encart of this book to other surviving exemplars (in Paris and Nice) confirms that all books had the same music, and that this music was sung monophonically, with all singers singing the same melodic line. There are, however, references to more elaborate singing at several points throughout the book. The section entitled "L'ordre divin du service," which provides instructions for the various services that the Congrégation held on a

63. The same instructions are present at corresponding points in the second and third offices at Matins (folio 27v and 51v, respectively, in the Heures de Nostre Dame 1583).

64. In place of the "Ave Maria," the Choristes and chœur sing the invitatory "Regem cui omnia vivunt, venite adoremus." The two Choristes then begin the first verse of the psalm. The presentation of the text, with indications of which groups sing which sections of the psalm and invitatory, follows the structure of the psalm in the musical section, but replaces the "Ave Maria" with the invitatory for the Office of the Dead. Presumably, the "Gloria patri et filio" is replaced by the "Requiem eternam." The different syllable count of the two texts would naturally require some adaptation of the music that is provided for the "Gloria patri" and "Ave Maria" when it is sung during the Office of the Dead. 
daily, weekly, monthly, and annual basis, refers to the singing of faux bourdon by the musiciens on several occasions. ${ }^{65}$ The term "faux-bourdon" appears at several places within the book and is always connected to the musiciens, but not the other singers we have seen thus far, which includes the two chœurs, the two Choristes, and the Recteur. This kind of singing was not a regular feature of all services, but took place twice a week on Wednesdays and Saturdays, and for special services throughout the year when the musiciens were present. ${ }^{66}$ The short directions on page 369 list the pieces to be sung in faux bourdon: "les Hymnes, le Benedicite omnia opera Domini, le Benedictus, le Magnificat, Nunc dimittis, le Miserere, ou quelque autre Pseaume [...] \& O sacrum convivium [...] \& quelque Mottet." ${ }^{67}$ The base melodies for all hymns and psalms are provided on page 4 of the musical encart, and the melody for the Benedicte is provided on page 5. The melodies for the Benedicite omnia opera Domini, and the Magnificat and Nunc dimitis are supplied on page 14. Since the music for the motets and the $O$ sacrum convivium is not included in the encart, the singers either used some of the melodies in the encart or drew on other music books. ${ }^{68}$

The singing of psalms also seems to have been of great importance for the Congrégation, so much so that they devoted a paragraph to it in the Statuts:

Les Pseaumes se commenceront par les Choristes alternatiuement, dont celuy qui sera au costé droict, commencera tousiours le premier, tournant la teste vers les Confreres de son costé, iusques à la moitié du premier verset, \& sera suiuy par le chœur qui sera de son costé, \& puis l'autre costé respondra, sinon que la Musique chantast, auquel cas les deux Choristes ensemble commenceront, \& la Musique continuera le premier verset

65. Heures de Nostre Dame 1583, 347 in the "Office de la Passion" and 369 in the "Lordre divin." Faux bourdon was a technique used for the singing of improvised polyphony in which a melody was accompanied by two lower parts singing in parallel sixths and fourths below the melody. The term musiciens refers to a special group of professional singers (see below).

66. The three obligatory processions and when the king was present.

67. Heures de Nostre Dame 1583, 369.

68. The motets could certainly have been notated in other books belonging to the Congrégation or the musiciens, though the author has not been able to identify or locate other music books belonging to this particular Congrégation. Please see the introduction in this issue by Dunn-Lardeau for information on other books belonging to later congregations of this confraternity, dated from the nineteenth century, including one which claims to be the thirteenth edition of a 1780 book. 
commencé, \& tous les Confreres ensemble feront l'autre chœur, \& ainsi se poursuiura alternatiuement. ${ }^{69}$

This passage reveals that the singing of psalms was the responsibility of the Choristes and the chours for everyday services, and of the musiciens-members of the Musique de Chambre of the king (see below) - when they were on site.

That the Confrères were also involved in the singing of psalms is evident from this passage. It actually fell into their regular duties, and rule 28 of the Statuts states that all Confrères were expected to learn the proper pronunciation and technique for the singing of the psalms. This was in keeping with Henri III's concern for the proper singing of chant, which would prompt a set of orders to his own singers in $1587 .{ }^{70}$

The Statuts also stipulates that all services should be sung, with the exception of the Mass, the Miserere, and the De profundis (Office of the Dead), the Salut for Notre Dame (featuring the great Marian antiphons), the seven penitential psalms, the litanies and the prayers that follow, the Litanies of the Passion, the Monday and Friday services of each year, and the services for Holy Week-except for the day of the Annonciation which, if it fell during Holy Week, should be sung, as could all services for the dead and processions, depending on the circumstances. ${ }^{71}$

The degree to which the Penitens themselves are involved in the regular singing of the hours during their various services-beyond the singing of psalms-is not clearly defined in the Statuts, nor is it explicitly stated in the hours themselves. There are references to "tous les Penitens" throughout the hours, such as at the beginning of Matins (see Fig. 5 of folio 1r).

69. Statuts, 68-69.

70. Abbé Oroux, Histoire ecclésiastique de la Cour de France, 2 vols. (Paris: Imprimerie royale, 1776-77), 2:190. Oroux also draws attention to the king's taste for faux bourdon. On the devotional practices of Henri III, see Bruno Petey-Girard, "Le mécénat de la parole: l'esthétique spirituelle dans les oratoires royaux," in Conihout, Maillard, and Poirier, eds., 169-78. Petey-Girard's article discusses Henri III's preference for elegant diction and for clear and precise singing in his personal devotions, which included singing during the Mass and the canonic hours.

71. Statuts, 47-48. The services for the dead and processions could feature singing in some certain circumstances. 
HEVRES DE NOSTRE DAME, POVR DIRE DEPVIS LE LENDEmain de la Purification troifiéme iour de Feurier, iufques aux vefpres duSamedy deuant le premier Dimanche de l'Aduent, excepréle iour de l'Annonciation, que l'on dit l'Office, comme durát I'Aduent, commençant depuis les Vefpres de la Vigile.

\section{A MATINES.}

Le Recteur fonnera la clochette, \& chacun fe mettra à genoux, \& ledit Recteur, la confefsion eftant faite, tout bas comme cy deflus, il commencera.

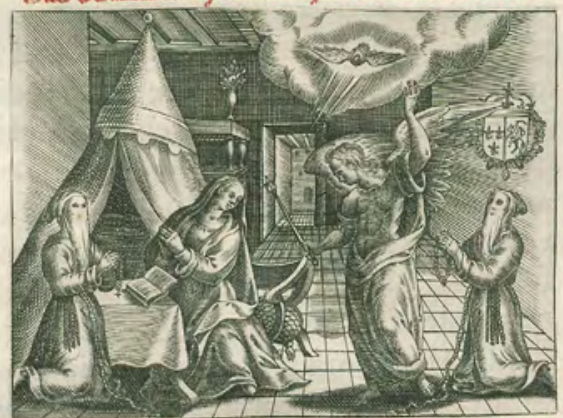

A Ve María, Agrátiaplena, Dóminus tecú. Le choeur de main droicterefpondra au mefme ton, Benedícta tu in mulićribus, \& bene. díctusfructus vé. tris tui Iefus. Le chour de main gauche fuyura, Sancta María mater Dei, ora pro nobis peccatóribus nunc \& in hora mortis noftrx. Tous enfemble refpondront.Amen.

Le Recteur faifant le figne de la Croix fur fes leures, entonnera.

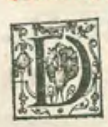

O'mine lábia mea apéries.

Tous les Penitens fe leueront \& refpondront.

Etosmeum annunciábit laudem tuam.

Puis faifant derechefle figne de la croix, depuislefront

2

Fig. 5. The Mettayer Hours of the Virgin, with an engraving and the opening "Ave Maria" and references to the two choirs and "tous les Penitens." Quebec City, Musée de l’Amérique francophone, 22.7.8 QMUC, folio 1r. 
The passage reads as follows : "Le Recteur, faisant le signe de la Croix sur les leures, entonnera. Domine labia mea aperies. Tous les Penitens se leveront \& respondront. Et os meum annunciabit laudem tuam." ${ }^{2}$ However, the singing of specific hymns or antiphons seems to have been assigned to a particular group referred to as "Le choeur," which was divided into two sections-one on the left-hand side of the chapel and the other on the right-hand side. The rubric on folio 48v of the Second Office concerning the singing of the great Marian antiphons indicates that some of the Penitens were in fact part of the chœur: "Et tous les Penitens de l'un ou l'autre choeur estans a genoux diront l'une ou l'autre des Antiennes suyvantes entonnées par les Choristes." 73 The overwhelming impression from the wording of the directions and the references to Choristes and chœurs, as well as "tous les Penitens," points to a specific group that was responsible for the singing of the music during the hours-both that which is included in the musical encart, and the other antiphons and hymns that were sung by the chours, musiciens, and the Choristes. According to the Statuts de la Congrégation, the Congrégation was required to keep a total of sixteen singers and musiciens. ${ }^{74}$ Among these sixteen members, four Choristes were required for the singing of the office (Hours of the Virgin), with two Choristes present for each service. ${ }^{75}$ These Choristes changed from year to year; in 1583, the king himself was one of the Choristes, along with the Cardinal of Guise. ${ }^{76}$ The Statuts also lists several other groups of singers, including a group of eight male musicians-the musiciens from the royal Musique de la chambre, who were themselves full members of the confraternity and were held to its statutes. Their sole responsibility was the singing of faux bourdon and other music for the Congrégation's chapels, ${ }^{77}$ which the Heures de Nostre Dame 1583 states also included the singing of motets. ${ }^{78}$ There were also two children from the royal Musique de la chambre who were required only for specific days, as well as

72. Heures de Nostre Dame 1583, folio 1r in the "Premier Office des Matines."

73. Heures de Nostre Dame 1583, folio 48v in the "Second Office de Vespres."

74. Statuts, $28,45$.

75. Statuts, 55. "Il y aura quatre Choristes, deux perpetuels, \& deux annuels, qui auront charge d'entonner tout l'Office, deux à chaque fois."

76. Jacqueline Boucher, Société et Mentalités autour de Henri III (Paris: Honoré Champion Éditeur, 2007), 1029.

77. Statuts, 59-60.

78. Heures de Nostre Dame 1583, 369. 
four male singers and two additional children who were needed at all services to sing the faux bourdons and other music, with only limited obligations to the Confraternity. ${ }^{79}$ The exact number of musicians/singers present for the regular offices is not always clear, though the two Choristes and four singers were certainly part of regular services, and the eight musiciens de la chambre were only present for special services. The children were not present at all times, although they were certainly part of the regular Wednesday service of the Hours-in which they sang the "Benedicite omnia opera," the Cantique des trois enfants-and for other important feasts throughout the year. ${ }^{80}$

\section{Singing or speaking the hours}

The first part of the book includes some references to the use of music other than that in the encart. Most of these were psalms, and in order for these texts to be sung the singers-usually the two Choristes-would have had to refer to the melody provided for other psalms on page 4 of the musical encart. ${ }^{81}$ We also find references throughout the book to "speaking" the text "a haute voix, mais sans chanter" and to "saying" the texts that would usually have been sung in a liturgical context. During Holy Week and for the Office of the Dead, the Choristes are instructed to lead the singing of psalms, but "a haute voix toujours sans chanter." ${ }^{2}$

79. Statuts, 60-61. The statutes stipulate that these four men and two children (if they are of age) will only be obliged to receive communion on the Feast of the Annunciation of the Virgin, and to observe the two-day fast stipulated in the first rule of the Statuts (61).

80. The Cantique des trois enfants appears in the Laudes of all three Offices of the Virgin in the Heures de Nostre Dame 1583 (fol. 10r, 35v, and 60r). "Benedicite omnia opera" was also part of the Roman liturgy for the Mass, and also for the French Easter Vigil Mass. See Clyde W. Brockett, "Benedicite, Persecutio, and Cantemus Domino in a Gallican (?) Ritual," in Atti del IV colloquio della Société internationale pour l'étude du théâtre médiéval: Viterbo 10-15 luglio 1983, ed. Maria Chiabò and Federico Doglio (Viterbo: Centro Studi sul Teatro Medioevale e Rinascimentale, 1984), 163-70; Ruth Steiner, "Antiphons for the Benedicite at Lauds," Journal of the Plainsong and Mediaeval Music Society 7 (1984): 1-17; Ruth Steiner, "The Canticle of the Three Children as a Chant of the Roman Mass," in La musique et le rite sacré et profane: actes du XIII congrès de la Société internationale de musicologie, Strasbourg, 29 août-3 septembre 1982, ed. Marc Honegger and Christian Meyer, 2 vols. (Strasbourg: Association des publicatons près les universités de Strasbourg, 1986), 2:300-71.

81. This is the case for "Dixit Dominus Domino" (Ps 109) on folio 21v of the "Premier Office de Vespres" (Purification to Advent) in the Heures de Nostre Dame 1583.

82. Heures de Nostre Dame 1583, “Office des morts," 1. 
The performance instructions for the great Marian antiphons during the Hours of the Virgin are also noteworthy. In the sixteenth century, the singing of the great Marian antiphons during evening services was often an occasion for the use of polyphony. But in Les Heures, the Congrégation appears to have spoken the antiphons. The instructions for the performance of the antiphons (in the Hours of the Virgin) direct "tous les Penitens" to "speak" the antiphon, which should be intoned by the two Choristes. ${ }^{83}$ The use of "speak" rather than "sing" is intriguing here. It could simply be that the Confrères sang the antiphon, and that "speak" may be understood as "sing." However, the use of the same word in the Statuts suggests that the Congrégation spoke the antiphon while the Choristes sang it. This hypothesis is supported by the fact that the word "chanter" is frequently used for other sung parts, but rarely in connection to "tous les Penitens," and by the reference in the Statuts to the Salut being performed without music. This kind of performance and the active participation of the Confrères points to a collective use for the Book of Hours, one that was markedly different from the usual, individual devotional practices of Books of Hours owners in the sixteenth century, and one that required the singing of the Hours.

\section{Conclusion}

To sum up, the Heures de Nostre Dame, a l'usage de Rome printed by Mettayer and Le Roy \& Ballard in 1583 and held at Musée de l'Amérique francophone in Quebec City reunites two significant traditions of the fifteenth and sixteenth centuries: the printed Book of Hours and the printed music book. The encart belongs to the rich tradition of sixteenth-century music printing and, more particularly, the French music printing tradition established by Attaingnant in the 1520s, including the use of the single impression printing method. It is a rare example of a music print produced by royal printers of music in collaboration with another printing house. It is likewise one of the few music prints from this era that were printed at the request of the king. ${ }^{84}$

\section{Heures de Nostre Dame 1583, folio 73v of the "Troisieme Office."}

84. There are no records that indicate that Attaingnant participated in this kind of project, nor do we have conclusive evidence that he printed music at the request of the king of France. 
What now seems obvious after our close examination of each section is that the two printing houses worked closely together. The relation of the encart to the text section of the book, and the overall conformity of the two sections in terms of physical appearance, point to a collaborative relationship between Mettayer and Le Roy \& Ballard, if only from the many cross-references to each other's part. Indeed, the organization of the music in the encart parallels the order of the texts in the Mettayer text section, with both sections opening with the "Ave Maria" antiphon. But the musical encart is much more than a supplementary gathering appended to the end of the book. The music printed by Le Roy \& Ballard corresponds directly to texts in the Mettayer text section which were to be sung by the various singers of the Congrégation. These singers, who included professional musicians from Henri III's own Musique de la chambre as well as Choristes chosen from among the Confrères and the two chours, required both parts of the Heures de Nostre Dame 1583 in order to perform the music for the services of the Congrégation. Only with both sections of the book do we arrive at a complete picture of the musical performance practice of the Congrégation, a practice that included solo performances by the Choristes and singing by young boys (the enfants), but also coordinated alternatim singing involving the Choristes and the two chours. The Statuts de la Congrégation des Penitens printed in 1583 by Mettayer are also integral to a full understanding of the musical practices of the Congrégation as they supply details of the number of singers retained by the Congrégation and provide important information concerning the proper singing of the psalms, details that are not included in the Mettayer or Le Roy \& Ballard sections but that are vital for the performance of the texts and music printed in the book. There are a number of aspects of the Heures de Nostre Dame 1583 that set it apart from traditional Books of Hours, most notably the inclusion of music within its pages in the form of the encart. It also features a high degree of integration between the music and text and includes precise performance directions, features that distinguish it from the other Books of Hours with music. ${ }^{85}$ Furthermore, although a complete study of the other Books of Hours with music has yet to be completed, it seems unlikely that the other books involve the kind of collaboration between two major printing houses that is evident in the Heures de Nostre Dame 1583. 
The Heures de Nostre Dame, a l'usage de Rome printed by Mettayer and Le Roy \& Ballard for the Congrégation des Penitens de l'Annonciation de Notre Dame held at the Musée de l'Amérique francophone is a splendid example of a post-Tridentine Book of Hours. It occupies a unique place in the histories of the printed Book of Hours and of the printed music book, as we have demonstrated in this article, as well as a special place in the inventory of Books of Hours held in Quebec collections. 